\title{
A scenario-based clean diesel production strategy for China National Petroleum Corporation
}

\author{
Liu Haiyan', Yu Jianning², Fan Yu', Shi Gang ${ }^{1}$ and Bao Xiaojun ${ }^{1 *}$ \\ ${ }^{1}$ The Key Laboratory of Catalysis, China National Petroleum Corporation, China University of Petroleum, Beijing 102249, P. \\ R. China \\ ${ }^{2}$ Department of R \& D Administration, China National Petroleum Corporation, Beijing 100724, P. R. China \\ (c) China University of Petroleum (Beijing) and Springer-Verlag Berlin Heidelberg 2011
}

\begin{abstract}
Facing increasingly strict environmental regulations on transportation fuels, China National Petroleum Corporation (CNPC), the second largest supplier of petroleum products in China, needs to upgrade its transportation fuels. Using the scenario-based analysis method, this paper analyzes how the output and emission related properties, including cetane number, and sulfur and aromatics contents of diesel produced by CNPC, will vary with changes in the configuration of diesel production units in the next 5-10 years. The results showed that, to upgrade its diesel, CNPC needs to adjust its diesel pool by decreasing the share of fluid catalytic cracking (FCC) diesel and increasing the shares of hydrocracking (HDC) and hydrotreating (HDT) diesel. Furthermore, to produce ultra-low-sulfur diesel, straight-run diesel as well as poor diesel blendstocks such as FCC diesel and coker diesel should be hydrotreated before being blended into finished diesel. Developing highly efficient HDC and HDT catalysts and corresponding processes is the key to CNPC economically producing more and cleaner diesel.
\end{abstract}

Key words: China National Petroleum Corporation, scenario analysis, clean diesel production

\section{Introduction}

As one of the largest producers and suppliers of refined petroleum products in China, China National Petroleum Corporation (CNPC) is playing a critical role in meeting the social and economic demands of China for petroleum products. By the end of 2009, CNPC's crude oil processing capacity had reached 125 million tonnes per annum, accounting for about $33.5 \%$ of the total capacity of about 370 million tonnes in China, and the output of the main petroleum products (including gasoline and diesel) was 80.4 million tonnes, accounting for $35.4 \%$ of the total output in China.

With the increasingly strict environmental regulations on transportation fuels, especially the ever-tighter specifications of sulfur content in gasoline and diesel, supplying more and cleaner gasoline and diesel is one of the most important commissions of CNPC's petroleum refining sector in the near future. Following the previous paper (Liu et al, 2008) that focused on CNPC's clean gasoline production strategy, this paper aims to discuss CNPC's clean diesel production strategy.

For diesel production, CNPC is facing two challenges: increasing its diesel output to meet the fast-growing demand,

\footnotetext{
* Corresponding author. email: baoxj@cup.edu.cn

Received September 9, 2010
}

and upgrading its diesel quality to meet the more stringent specifications.

The world demand for diesel has been growing faster than that for gasoline since the mid-1990s. It is estimated that the world demand for diesel will increase from 23 million barrels/day (MB/D) in 2005 to $37 \mathrm{MB} / \mathrm{D}$ in 2025, while the demand for gasoline will increase from $21 \mathrm{MB} / \mathrm{D}$ in 2005 to $27.5 \mathrm{MB} / \mathrm{D}$ in 2025 (Donald et al, 2007). In China, the diesel to gasoline consumption ratio had actually increased from 1.32 in 1995 to 2.04 in 2009, and it is estimated that this ratio would reach 2.30 in 2020. Therefore, increasing diesel to gasoline production ratio is also one of the main tasks for Chinese oil refiners.

In China's commercial diesel pool, straight run (SR) diesel and fluid catalytic cracking (FCC) diesel (usually known as FCC light cycle oil (LCO), and denoted as FCC LCO hereafter) are the dominant blendstocks, with SR diesel and FCC diesel taking shares of about $50 \%$ and about $30 \sim 40 \%$ (Ma, 2001; Hou, 2001), respectively, and other blendstocks including hydrocracking (HDC) diesel and thermal cracking diesel accounting for only about $10 \%$.

FCC LCO is an unfavorable diesel-fuel blending component due to its poor engine ignition and high aromatics content of 50-80 wt\% (Hou, 2005). China's oil refiners did not realize that upgrading FCC diesel by hydrotreating (HDT) techniques is an effective measure to upgrade their diesel 
until 2005 when the Chinese national standard GB/T 191472003 on transportation diesel came into effect. Since then various HDT techniques including MHUG (Mild Hydroupgrading) and MCI (Maximum Cetane Improvement) have been developed. However, just upgrading FCC diesel does not guarantee CNPC to produce clean diesel that meets the stricter and stricter regulations on sulfur and aromatics contents.

In summary, CNPC is facing the challenges of increasing its diesel output to meet the fast-growing demand and upgrading its diesel quality to meet the more stringent specifications. To search for possible solutions for CNPC to produce more and cleaner diesel in the next 5-10 years, by using a scenario analysis method this paper shows how changes in the configuration of CNPC's diesel production units would influence the quantity and quality of CNPC's diesel and how CNPC could update its clean diesel production technologies. Part of the results presented in this paper had been adopted in the "Eleventh Five-Year Research \& Technology Development Strategy of CNPC".

\section{Methodology}

In view of the relative uniqueness in its configuration of petroleum processing units, CNPC is facing several challenges to upgrade its diesel. Firstly, the insufficient supply of domestic low-sulfur crude oil will aggravate the difficulty for oil refineries to produce clean transportation fuels, especially ultra-low-sulfur diesel (ULSD). China's refiners have to process more and more imported crude oils in which about $33 \%$ are heavy ones with high sulfur content (Tian, 2007). Secondly, most of the Chinese refineries have limited capacities of HDC and HDT units. Actually, in 2006, the capacities of HDC and HDT in China were only 25.96 and 97.50 million tonnes per annum (Mt/a), respectively (Zhang, 2008), much smaller than those of the North America (88.0 and 735.6 Mt/a, respectively) (David, 2006). Thirdly, the future regulations on vehicle fuels will be stricter and stricter to reduce the pollutant emissions from gasoline- and diesel-powered automobiles. For diesel, the requirement is to produce clean diesel with high cetane number, low sulfur and aromatics contents.

Confronted with the above-mentioned challenges, CNPC has more than one choice to produce clean diesel: (1) reformulating its diesel pool, (2) increasing its capacity of HDC units to produce high-quality HDC diesel, or (3) increasing the capacity of HDT units to upgrade FCC diesel and/or other poor diesel blendstocks. So, the future development of CNPC's clean diesel production is far from predetermined.

So, embodying a wide variety of ideas about the future and integrating them in a communicable way can form a set of carefully crafted stories, or scenarios (de Jouvenel, 2000). Following the principles and development stages of the scenario-analysis method we have reported in the previous papers (Liu et al, 2006; 2008), herein we present two types of scenario to show how the quality and quantity of diesel could be enhanced by CNPC in the next 5-10 years. The first type of scenarios (Scenarios 1 to 6 and Scenarios I to VI shown in Tables 1 and 2, respectively) is aimed at investigating how the diesel quality would vary with changes in the diesel pool configuration. The second type of scenarios (Scenarios 8 to 11 as shown in Figs. 2 to 5 in Section 3.2) is aimed at investigating how CNPC's diesel pool configuration and output would vary with changes in the configuration of diesel production units. Based on the scenario analysis, in Section 3.3 we discuss the corresponding measures for CNPC to upgrade its clean diesel production technologies.

Table 1 Scenarios of diesel pool configurations of CNPC

\begin{tabular}{|c|c|c|c|c|c|c|}
\hline & \multirow{2}{*}{$\begin{array}{c}2005 \\
\text { Scenario } 1\end{array}$} & \multirow[b]{2}{*}{ Scenario 2} & \multicolumn{2}{|c|}{2015} & \multicolumn{2}{|c|}{2020} \\
\hline & & & Scenario 3 & Scenario 4 & Scenario 5 & Scenario 6 \\
\hline SR diesel & $50 \%$ & $50 \%$ & $50 \%$ & $50 \%$ & $50 \%$ & $50 \%$ \\
\hline FCC diesel & $30 \%$ & $30 \%$ & $20 \%$ & $10 \%$ & $20 \%$ & $10 \%$ \\
\hline HDC diesel & $10 \%$ & $20 \%$ & $20 \%$ & $30 \%$ & $30 \%$ & $40 \%$ \\
\hline Other $^{\mathrm{a}}$ & $10 \%$ & $0 \%$ & $10 \%$ & $10 \%$ & $0 \%$ & $0 \%$ \\
\hline \multicolumn{7}{|l|}{ Quality of diesel } \\
\hline Cetane number & 42.7 & 43.8 & 46.5 & 50.3 & 47.5 & 51.3 \\
\hline Aromatics, v\% & 39.6 & 38.4 & 33.1 & 26.7 & 31.9 & 25.5 \\
\hline Sulfur, $\mu \mathrm{g} / \mathrm{g}$ & 4457 & 4454 & 3059 & 1661 & 3056 & 1658 \\
\hline
\end{tabular}

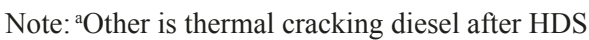

Using the diesel pool configuration of CNPC in 2005 as the base scenario (Scenario 1 shown in Table 1), the first type of scenario is developed by gradually decreasing the share of FCC diesel and increasing that of high-quality HDC diesel, and Scenarios I to VI in Table 2 are derived from their counterparts in Table 1, with part of or all of SR diesel and FCC diesel being hydrodesulfurized (HDS). For example, Scenario I is derived from Scenario 1, i.e., while the diesel pool configurations of the both scenarios are composed of $50 \%$ SR diesel, 30\% FCC diesel, 10\% HDC diesel, and 10\% 
other thermal cracking diesel, in Scenario I 10\% SR diesel and $30 \%$ FCC diesel are hydrodesulfurized.

\section{Results and discussion}

\subsection{Diesel quality}

To investigate the change of CNPC's diesel quality in various scenarios, we must define the main blendstocks and relate their blending proportions in the commercial diesel pool with some key quality specifications of clean diesel, such as cetane number, sulfur content, and aromatics content. The main emission-related properties of typical diesel blendstocks, such as SR diesel, thermal cracking diesel, FCC diesel, HDC diesel and HDS diesel, are summarized in Table 3 (Wu, 2004), where the HDS includes the highintensity HDS (HIDS) and the quality of HDS diesel depends significantly upon feedstock and operating conditions such as hydrogen pressure and temperature.

Table 2 Scenarios of diesel pool configurations of CNPC

\begin{tabular}{|c|c|c|c|c|c|c|}
\hline \multirow{2}{*}{ Blendstocks } & \multirow{2}{*}{$\begin{array}{c}2005 \\
\text { Scenario I }\end{array}$} & \multicolumn{3}{|c|}{2015} & \multicolumn{2}{|c|}{2020} \\
\hline & & Scenario II & Scenario III & Scenario IV & Scenario V & Scenario VI \\
\hline SR diesel & $40 \%$ & $35 \%$ & $25 \%$ & $15 \%$ & $10 \%$ & $0 \%$ \\
\hline HDS SR diesel $^{\mathrm{a}}$ & $10 \%$ & $15 \%$ & $25 \%$ & $35 \%$ & $40 \%$ & $50 \%$ \\
\hline FCC diesel & $0 \%$ & $0 \%$ & $0 \%$ & $0 \%$ & $0 \%$ & $0 \%$ \\
\hline HDS FCC diesel ${ }^{\mathrm{b}}$ & $30 \%$ & $30 \%$ & $20 \%$ & $10 \%$ & $20 \%$ & $10 \%$ \\
\hline HDC diesel & $10 \%$ & $20 \%$ & $20 \%$ & $30 \%$ & $30 \%$ & $40 \%$ \\
\hline Other $^{\mathrm{c}}$ & $10 \%$ & $0 \%$ & $10 \%$ & $10 \%$ & $0 \%$ & $0 \%$ \\
\hline \multicolumn{7}{|l|}{ Quality of diesel } \\
\hline Cetane number & 56 & 52 & 52 & 53 & 53 & 54 \\
\hline Aromatics, v\% & 22.8 & 21.1 & 20.1 & 17.9 & 17.4 & 15.2 \\
\hline Sulfur, $\mu \mathrm{g} / \mathrm{g}$ & 277 & 202 & 156 & 109 & 86 & 38 \\
\hline
\end{tabular}

Notes: ${ }^{a} \mathrm{HDS}$ SR diesel is SR diesel after HDS; ${ }^{\mathrm{b}} \mathrm{HDS}$ FCC diesel is FCC diesel after HDS; ${ }^{\mathrm{c}} \mathrm{Other}$ is thermal cracking diesel after HDS

Table 3 Emission-related properties of different diesel blendstocks

\begin{tabular}{cccccc}
\hline & \multicolumn{4}{c}{ Properties } \\
\cline { 2 - 5 } Blendstocks & $\begin{array}{c}\text { Sulfur } \\
\mu \mathrm{g} / \mathrm{g}\end{array}$ & $\begin{array}{c}\text { Aromatics } \\
\mathrm{v} \%\end{array}$ & Cetane number & $\begin{array}{c}\text { Cloud point } \\
{ }^{\circ} \mathrm{C}\end{array}$ & $\begin{array}{c}\text { Nitrogen } \\
\mu \mathrm{g} / \mathrm{g}\end{array}$ \\
\hline SR diesel & $3-20000$ & $20-40$ & $42-54$ & $-10-+5$ & $90-400$ \\
Thermal cracking diesel & $>20000$ & $30-60$ & $28-45$ & $-4--8$ & $625-1500$ \\
FCC diesel & 14000 & $60-85$ & $18-27$ & -10 & $625-1250$ \\
HDC diesel & $<20$ & 8 & $>60$ & $<-15$ & - \\
HDS diesel & $<50$ & $<20$ & $>50$ & -
\end{tabular}

Cetane number is a measurement of combustion quality of diesel during compression ignition. It is one of the most important quality specifications for diesel and is related to the aromatics content of diesel. It has been found that sulfur content in diesel is not only responsible for sulfurous compound emissions but is also related to other pollutants, such as particulate matter emissions. As seen from Table 3, among the various diesel blending components, only HDC diesel and HDS diesel can approximately meet all the present quality specifications on cetane number $(>50)$, sulfur content $(<50 \mu \mathrm{g} / \mathrm{g})$, and aromatics content $(<20 \mathrm{v} \%)$ as regulated in the United States, Europe, Japan, and China (see Table 4), but their production capacities are so limited in China that currently they cannot be considered as the primary diesel blending components for most of the Chinese oil refineries.
So, in all the twelve scenarios SR diesel is still chosen as the primary blending component, accounting for $50 \%$ in finished diesel, and the share of FCC diesel is decreased gradually from $30 \%$ in Scenario 1(I) to $10 \%$ in Scenario 6(VI), while HDC diesel is increased from $10 \%$ to $40 \%$ correspondingly. The diesel properties including cetane number, sulfur content and aromatics content in finished diesel are estimated according to the shares and properties of the various diesel components listed in Table 3. The estimations are made by assuming that: the cetane number, aromatics content and sulfur content of SR diesel are $50,30 \mathrm{v} \%$, and $500 \mu \mathrm{g} /$ $\mathrm{g}$, respectively; those of FCC diesel are 22.5, $72.5 \mathrm{v} \%$ and $14,000 \mu \mathrm{g} / \mathrm{g}$, respectively; those of HDS diesel (HDS SR diesel, HDS FCC diesel, and HDS thermal cracking diesel) are $50,20 \mathrm{v} \%$ and $50 \mu \mathrm{g} / \mathrm{g}$, respectively; and those of HDC 
diesel are $60,8 \mathrm{v} \%$ and $20 \mu \mathrm{g} / \mathrm{g}$, respectively. The results are shown in Tables 1 and 2. The approximate calculation formulas used are as follows:

$$
\begin{aligned}
& \text { Cetane number }=50 \times R_{\mathrm{SR}}+22.5 \times R_{\mathrm{FCC}}+60 \times R_{\mathrm{HDC}} \\
& \quad+50 \times R_{\mathrm{HDS}+\text { oth }}
\end{aligned}
$$

$$
\begin{aligned}
& \operatorname{Sulfur}(\mu \mathrm{g} / \mathrm{g})=500 \times R_{\mathrm{SR}}+14000 \times R_{\mathrm{FCC}}+20 \times R_{\mathrm{HDC}} \\
& \quad+50 \times R_{\mathrm{HDS}+\text { oth }}
\end{aligned}
$$

$$
\begin{aligned}
& \text { Artomatics }(\mathrm{v} \%)=30 \times R_{\mathrm{SR}}+72.5 \times R_{\mathrm{FCC}}+8 \times R_{\mathrm{HDC}} \\
& \quad+20 \times R_{\mathrm{HDS}+\text { oth }}
\end{aligned}
$$

where $R_{\mathrm{SR}}$ stands for the share of SR diesel, $R_{\mathrm{FCC}}$ the share of FCC diesel, $R_{\mathrm{HDC}}$ the share of HDC diesel, $R_{\mathrm{HDS}+\text { oth }}$ the sum of the shares of HDS SR diesel, HDS FCC diesel and other HDS diesel. One thing should be stated, this is that the cetane number of finished diesel always varies nonlinearly with its composition.

From Table 1, It can seen that the cetane number of the finished diesel increases with decreasing ratio of FCC diesel and increasing ratio of HDC diesel from Scenario 1 to Scenario 6. Compared with Scenario 1, decreasing FCC diesel ratio to $10 \%$ and increasing HDC diesel ratio to $40 \%$ in Scenario 6 result in a cetane number of 51.3 of the finished diesel, in full compliance with the cetane specification of China III and China IV (China IV is now in the committee stage) standards (see Table 4). Meanwhile the sulfur and aromatics contents drop to $1,658 \mu \mathrm{g} / \mathrm{g}$ and $25.5 \mathrm{v} \%$, respectively, still much higher than the sulfur and aromatics specifications of China III and China IV Standards. This indicates that just reformulating the diesel blending pool by decreasing FCC diesel and increasing HDC diesel is not sufficient for CNPC to upgrade its diesel. Intuitively, the best way for CNPC to produce low-sulfur

\begin{tabular}{|c|c|c|c|c|c|}
\hline & & $\begin{array}{l}\text { Sulfur } \\
\mu \mathrm{g} / \mathrm{g}\end{array}$ & $\begin{array}{c}\text { Aromatics } \\
\text { v } \%\end{array}$ & Cetane number & Year \\
\hline \multirow{2}{*}{\multicolumn{2}{|c|}{ The United States }} & 50 & & 58 & 2005 \\
\hline & & 15 & $10-20$ & $>40^{\mathrm{c}}$ & 2010 \\
\hline \multirow{3}{*}{\multicolumn{2}{|c|}{ Europe }} & 350 & $11^{\mathrm{b}}$ & 51 & 2000 \\
\hline & & 50 & - & - & 2005 \\
\hline & & 10 & $10-20$ & - & 2009 \\
\hline \multirow{2}{*}{\multicolumn{2}{|c|}{ Japan }} & 50 & & $>45$ & 2004 \\
\hline & & 10 & & & 2007 \\
\hline \multirow{2}{*}{ China } & China III ${ }^{\mathrm{a}}$ & 350 & $11^{\mathrm{b}}$ & 51 & 2007 \\
\hline & China IV (in committee stage) ${ }^{\mathrm{a}}$ & 50 & $1^{\mathrm{b}}$ & 51 & 2013 \\
\hline & Beijing, China & $<50$ & $<11^{\mathrm{b}}$ & $47-50$ & March, 2008 \\
\hline
\end{tabular}
diesel is to upgrade its poor-quality diesel blendstocks by HDS techniques, and for this reason Scenarios I to VI are developed and shown in Table 2.

As seen in Table 2, the diesel cetane number of

Table 4 Main quality specifications of clean diesel in the United States, Europe, Japan and China

Notes: ${ }^{a}$ China III and China IV standards are almost equivalent to EURO III and EURO IV standards, respectively; ${ }^{\text {DData }}$ are for polyaromatics; ${ }^{\mathrm{c}}$ Cetane number index

Scenario I, which is developed on the basis of Scenario 1 with hydrodesulfurizing $10 \%$ SR diesel and $30 \%$ FCC diesel, is increased from 42.7 of Scenario 1 to 56 , and the sulfur content is greatly decreased from 4,457 to $277 \mu \mathrm{g} /$ $\mathrm{g}$, indicating that HDS technique is an effective upgrading measure. Correspondingly, , the diesel sulfur content of Scenario VI is dramatically decreased from $1,658 \mu \mathrm{g} / \mathrm{g}$ of Scenario 1 to $38 \mu \mathrm{g} / \mathrm{g}$ that meets the sulfur specification of the current regulations of China (see Table 4). The influences of hydrodesulfurizing SR diesel and FCC diesel on the cetane number, aromatics content and sulfur content are shown in Fig. 1(a), (b) and (c), respectively.

As seen in Fig. 1(a), the cetane number increases with decreasing ratio of FCC diesel and increasing ratio of HDC diesel for Scenarios 1 to 6 , meanwhile with increasing ratio of HDS diesel for Scenarios I to VI, the cetane number increases, too. This indicates that oil refineries have two options to improve the diesel cetane number: one is to reformulate their diesel pool by increasing the ratio of highquality diesel blendstock such as HDC diesel, and the other is to upgrade their poor-quality diesel blendstocks such as FCC diesel and SR diesel by HDS techniques. More importantly, HDS is more effective in increasing the cetane number of finished diesel.

The situation for aromatics is the same as that for sulfur contents. With increasing HDC diesel ratio from Scenario 1 to Scenario 6, the aromatics and sulfur contents decrease gradually (see Fig. 1(b) and (c)), but the aromatics content 

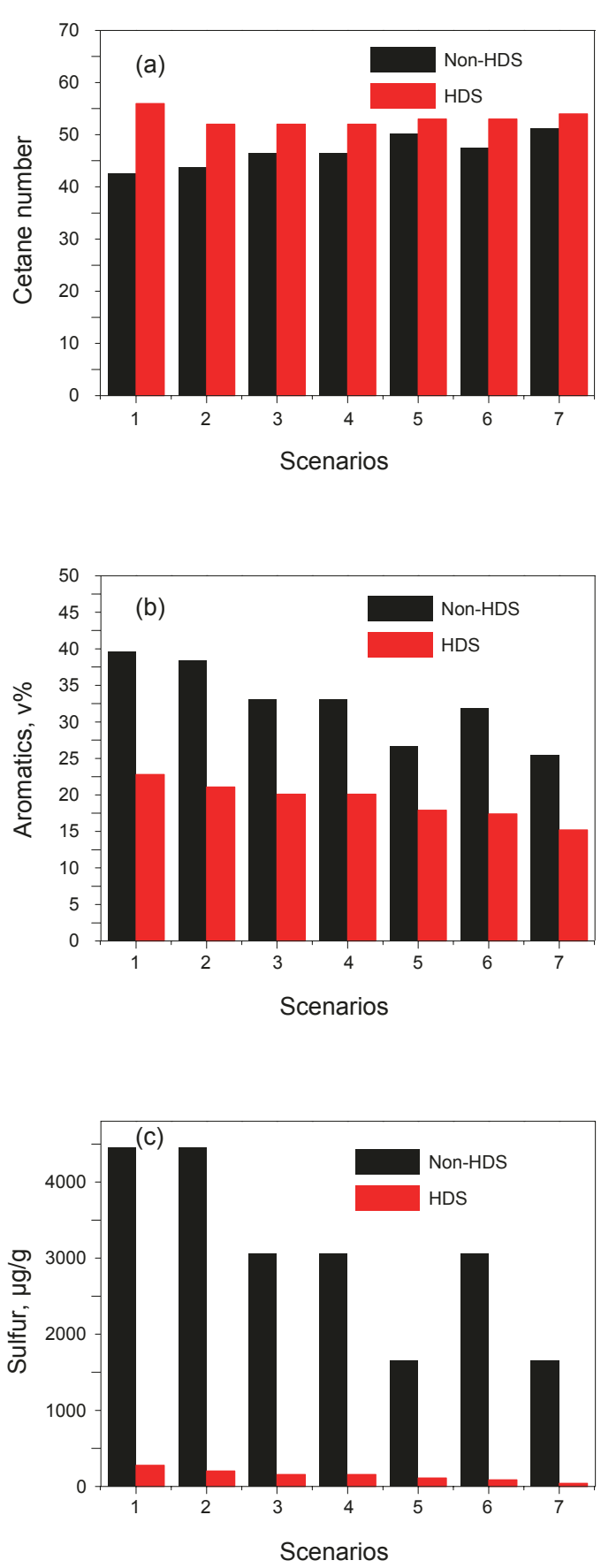

Fig. 1 Comparison of diesel qualities with HDS and without HDS in different scenarios Ccetane number; (b) Aromatics content; (c) Sulfur content.

$(25.5 \mathrm{v} \%)$ and sulfur content $(1,658 \mu \mathrm{g} / \mathrm{g})$ in Scenario 6 are still much higher than the specifications regulated in China and other countries. While from Scenario I to Scenario VI, with increasing HDS diesel ratio, the aromatics and sulfur contents decrease greatly. The aromatics content of $15.2 \mathrm{v} \%$ and sulfur content of $38 \mu \mathrm{g} / \mathrm{g}$ in Scenario VI can approximately meet the specifications, indicating that HDS is the most effective measure to significantly decrease the sulfur and aromatics contents of finished diesel.

Actually, sulfur content of worldwide diesel fuels has been reduced at a very fast pace since Germany mandated a maximum sulfur level of $10 \mu \mathrm{g} / \mathrm{g}$ in January, 2003. The
United States mandated its sulfur specification of $15 \mu \mathrm{g} / \mathrm{g}$ in 2006, Japan planned to control it to $10 \mu \mathrm{g} / \mathrm{g}$, and several other European countries voluntarily switched it to $10 \mu \mathrm{g} / \mathrm{g}$ ahead of the deadline 2009. By the end of $2010,45 \%$ of diesel worldwide will be of ultra-low sulfur (Donald et al, 2007).

From the above analysis, we can conclude that to meet the ever-tightened regulations on transportation diesel, especially to produce ULSD, just reformulating the diesel pool by decreasing poor-quality diesel blendstocks and increasing high-quality diesel blendstocks or just upgrading its FCC diesel is not adequate for CNPC to upgrade its diesel. SR diesel, FCC diesel and thermal cracking diesel are responsible for high sulfur content in finished diesel. Therefore, SR diesel as well as other poor diesel blendstocks must be hydrotreated before being blended into the finished diesel pool.

\subsection{Configuration of CNPC's clean diesel production units}

To reformulate its diesel pool, CNPC needs to reconfigure its diesel production units. To understand the variation of CNPC's diesel quality and quantity with changes in the configuration of its production units, scenarios 8 to 11 was developed, as shown in Figs. 2 to 5.

As diesel production units are usually integrated with gasoline production units, therefore the configurations of CNPC's clean gasoline and diesel production units in 2015 and 2020 are predicted and shown in Figs. 2 to 5, respectively. The units for clean gasoline production include those of FCC, reformation, alkylation, methyl tertbutyl ether (MTBE), isomerization and coking processes, and the units for clean diesel production include those of atmospheric distillation, FCC, HDC and coking processes. For compliance with the stricter and stricter specifications on sulfur, olefins and aromatics contents in the future, FCC naphtha, FCC LCO, thermal naphtha, and thermal cracking diesel should be hydrotreated before being blended into finished products.

Yuan (2005) predicted that by 2010 and 2020, the crude oil processing capacity of China would be 350 and $470 \mathrm{Mt} / \mathrm{a}$, respectively. So, we can predict that by 2015 the crude oil processing capacity of China would be about $410 \mathrm{Mt} / \mathrm{a}$. Correspondingly, the crude oil processing capacities of CNPC by 2015 and 2020 would be 164 and 188 Mt/a, respectively, assuming that CNPC maintains its current share (about 40\%) of crude oil processing capacity in China.

As shown in Figs. 2 and 3, CNPC's FCC capacities in 2015 and 2020 will remain at $46.56 \mathrm{Mt} / \mathrm{a}$ (equal to that in 2003), and FCC feedstock will be composed of $65.0 \%$ VGO (vacuum gas oil) and $35.0 \% \mathrm{VR}$ (vacuum residue). It should be noted that both VGO and VR are produced from vacuum distillation units and their yields are about $30.0 \%$ and $43.0 \%$, respectively. The remaining VGO is used as HDC feedstock to produce HDC diesel, and part of the rest of the VR is sent to cokers to produce coking naphtha and diesel. Therefore, in Scenarios 8 and 9, FCC still takes a dominant position in the secondary processing units, i.e., these configurations are FCC-based. The yield of straight-run naphtha will be $7.33 \%$, in which the lighter (about 25\%) and heavier (about 75\%) fractions can be used to produce isomerate and reformate, 


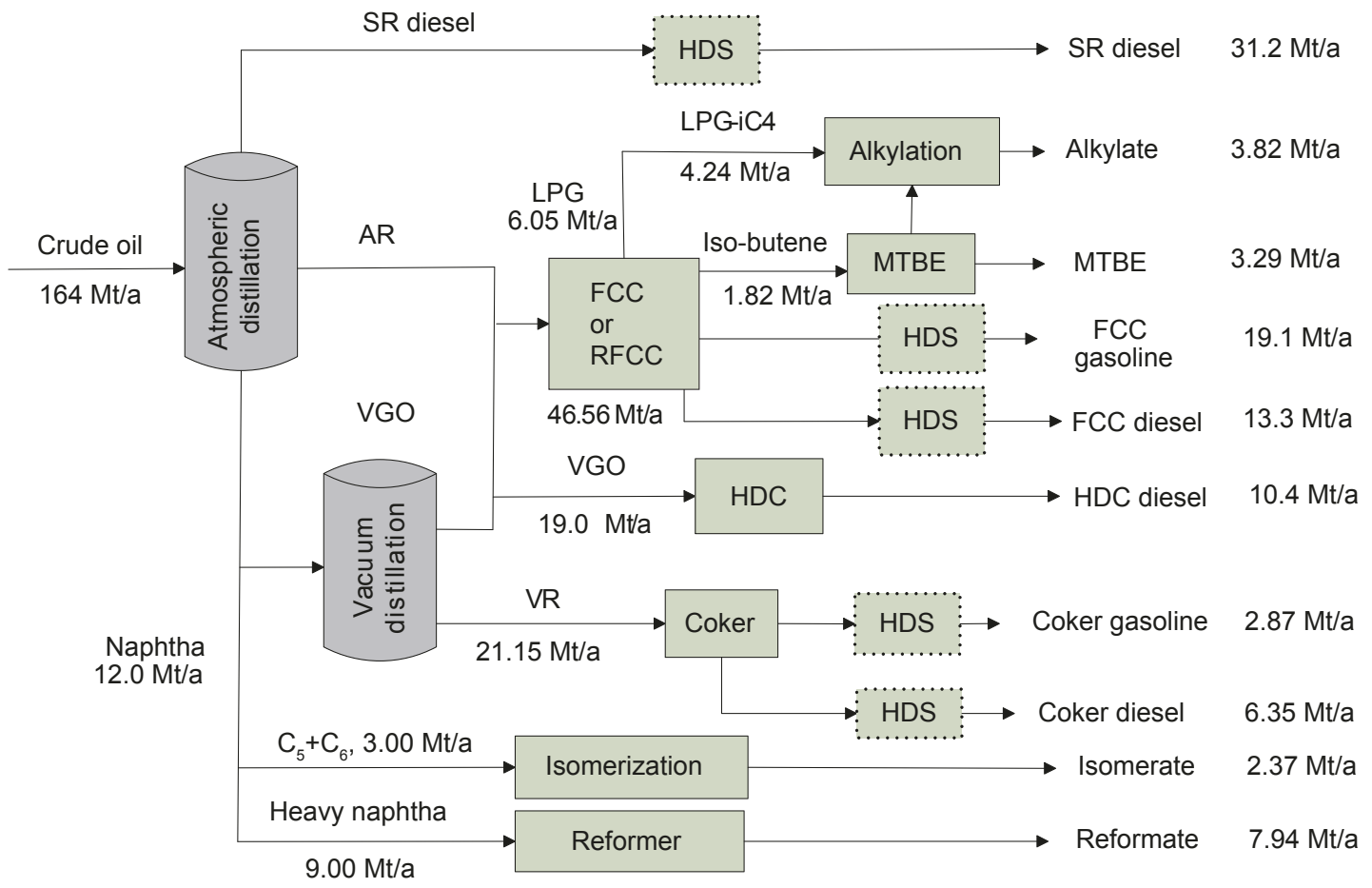

Fig. 2 Scenario 8: configuration of clean gasoline and diesel production units of CNPC in 2015 (FCC-based)

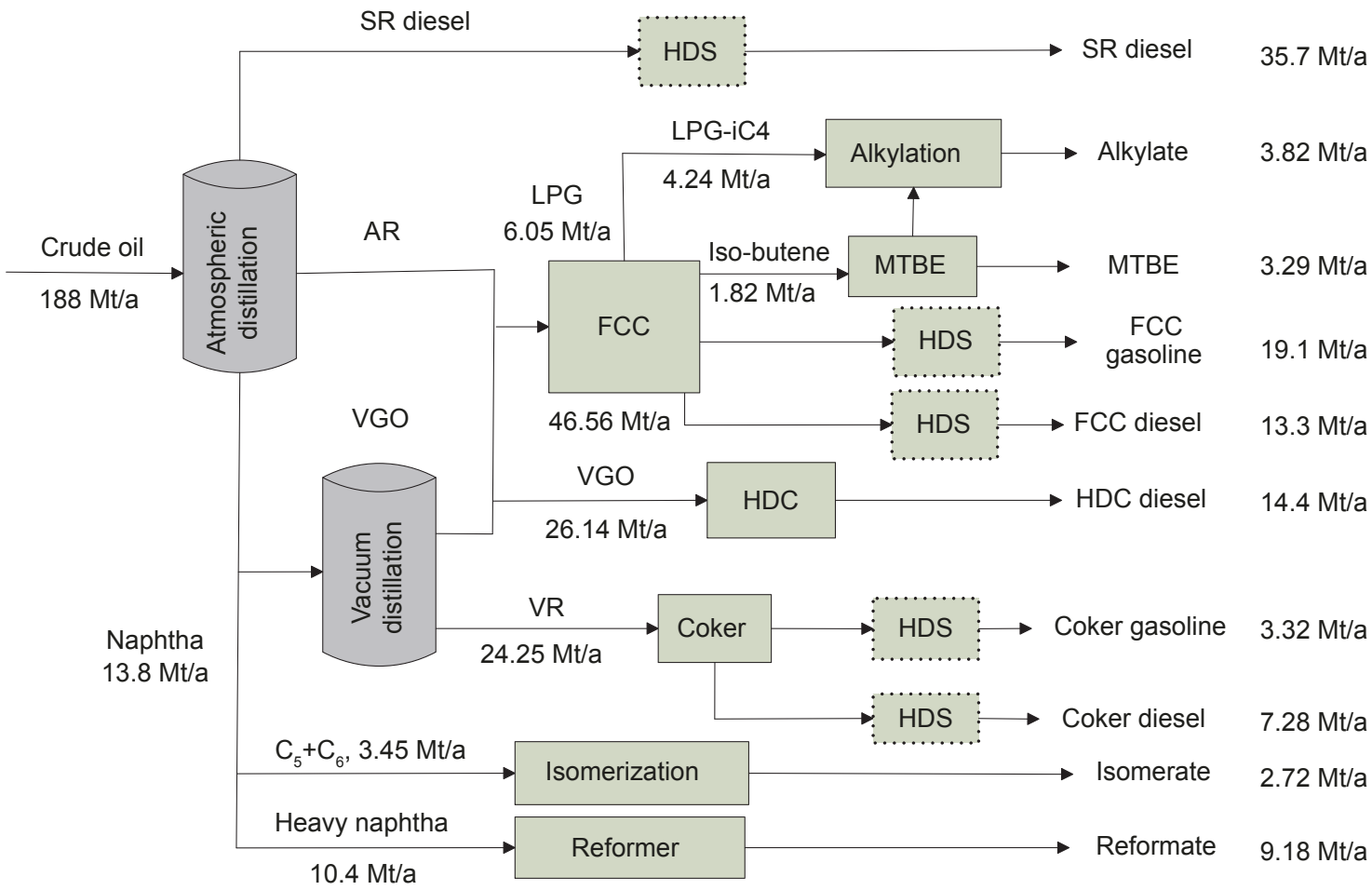

Fig. 3 Scenario 9: configuration of clean gasoline and diesel production units of CNPC in 2020 (FCC-based)

respectively. The feedstock of MTBE and alkylation units is liquefied petroleum gas (LPG) from FCC units and the feedstock of cokers is VR that accounts for $30 \%$ of the total VR from vacuum distillation units. Theoretically, the outputs of various gasoline and diesel components and their proportions in the finished gasoline and diesel pools in 2015 and 2020 can be estimated and the results are shown in Table 5.
The gasoline component output and diesel component output are calculated according to their average yields in gasoline and diesel production units, respectively, as listed in Table 6.

In Scenario 8 for 2015, CNPC's crude oil processing capacity would be $164 \mathrm{Mt} / \mathrm{a}$ and FCC capacity would be 46.56 $\mathrm{Mt} / \mathrm{a}$, and the theoretical outputs of finished gasoline and diesel would be 39.39 and 61.25 million tonnes, respectively, 
giving a diesel/gasoline ratio of 1.55 . The gasoline pool consists of $48.5 \%$ FCC gasoline, $20.2 \%$ reformate, $9.70 \%$ alkylate, $6.02 \%$ isomerates, $8.35 \%$ MTBE, and $7.29 \%$ thermal naphtha. The diesel pool consists of $50.9 \%$ SR diesel, $21.7 \%$ FCC diesel, 17.0\% HDC diesel and 10.4\% coker diesel. This diesel pool configuration is similar to that of Scenario 3(III) in 2015.

Table 5 CNPC's yields of gasoline and diesel in 2015 and 2020

\begin{tabular}{|c|c|c|c|c|}
\hline & \multicolumn{2}{|c|}{2015} & \multicolumn{2}{|c|}{2020} \\
\hline & Scenario 8 & Scenario 10 & Scenario 9 & Scenario 11 \\
\hline & FCC-based & HDC-based & FCC-based & HDC-based \\
\hline Diesel, Mt/a & 61.25 & 74.62 & 70.68 & 85.38 \\
\hline Gasoline, $\mathrm{Mt} / \mathrm{a}$ & 39.39 & 32.80 & 41.43 & 37.72 \\
\hline Diesel/Gasoline ratio & 1.55 & 2.27 & 1.71 & 2.26 \\
\hline \multicolumn{5}{|l|}{ Gasoline pool, \% } \\
\hline FCC gasoline & 48.5 & 43.6 & 46.1 & 43.5 \\
\hline Reformate & 20.2 & 24.2 & 22.2 & 24.3 \\
\hline Alkylate & 9.70 & 8.72 & 9.22 & 8.70 \\
\hline MTBE & 8.35 & 7.50 & 7.94 & 7.48 \\
\hline Isomerate & 6.02 & 7.23 & 6.57 & 7.21 \\
\hline Coker naphtha & 7.29 & 8.75 & 8.01 & 8.80 \\
\hline \multicolumn{5}{|l|}{ Diesel pool, \% } \\
\hline SR diesel & 50.9 & 41.8 & 50.5 & 41.8 \\
\hline FCC diesel & 21.7 & 13.4 & 18.8 & 13.4 \\
\hline HDC diesel & 17.0 & 36.3 & 20.4 & 36.3 \\
\hline Coker diesel & 10.4 & 8.51 & 10.3 & 8.53 \\
\hline
\end{tabular}

Table 6 Average yields of main gasoline and diesel components (PetroChina, 2004; Hou, 2001)

\begin{tabular}{ll}
\hline & Yields, wt $\%$ \\
\hline FCC naphtha & 41.11 \\
Reformate & 88.30 \\
Alkylate & $>90^{\mathrm{a}}$ \\
Isomerate & 78.88 \\
Coker naphtha & 13.70 \\
\hline Diesel components & \\
SR diesel & 19.00 \\
FCC diesel & 28.55 \\
HDC diesel & 55.00 \\
Coker diesel & 30.00 \\
\hline
\end{tabular}

Note: ${ }^{a}$ based on feedstock
In Scenario 9 for 2020 when CNPC's crude oil processing capacity and FCC capacity reach $188 \mathrm{Mt} / \mathrm{a}$ and $46.56 \mathrm{Mt} / \mathrm{a}$, respectively, the predicted outputs of finished gasoline and diesel are 41.43 and $70.68 \mathrm{Mt} / \mathrm{a}$, respectively, and the diesel/ gasoline ratio is increased to 1.71 . Then, the gasoline pool consists of $46.1 \%$ FCC gasoline, $22.2 \%$ reformate, $9.22 \%$ alkylate, $6.87 \%$ isomerate, $7.94 \% \mathrm{MTBE}$, and $8.01 \%$ thermal naphtha. The diesel pool consists of $50.5 \%$ SR diesel, $18.8 \%$ FCC diesel, 20.4\% HDC diesel and 10.3\% coker diesel, also similar to that in Scenario 3(III) for 2015. That is to say, even by reconfiguring its diesel production units as described in Scenarios 8 and 9, CNPC can not upgrade its diesel nor increase the diesel to gasoline production ratio dramatically.

From the above analysis, it can be seen that for CNPC to produce more and cleaner diesel with higher cetane number and lower aromatics and sulfur contents, the proportion of HDC diesel must be increased in finished diesel.

As mentioned above, HDC diesel, because of its high cetane number, low aromatics and sulfur contents, is the only one that can be blended directly into the finished diesel pool. Except for that, with rising sulfur content of the feedstocks to oil refineries, HDC techniques are playing an increasingly prominent role in many refinery configurations to upgrade poor feedstocks to lighter valuable fractions such as transportation fuels. It was estimated from 2005 to 2015 , HDC capacity would be increased by more than $60 \%$ over the world, while in the same period FCC capacity would be increased by only about $10 \%$ (Donald et al, 2007). Furthermore, almost all the oil refineries in the world are facing the challenges of increasing their diesel outputs to meet the fast-growing demand. In fact, HDC operations can be adapted for maximizing gasoline, jet fuel or diesel production. For example, the integrated two-stage moderatepressure HDC (MPHC) process is a commercially proven approach, which allows refinery to selectively hydrocrack VGO and to maximize the production of high-quality Jet A1 and diesel products. This unique technology uses a proprietary catalyst system and takes advantage of two different chemical reactions: hydrocracking and selective hydroisomerization hydrocracking, both of which can be operated at moderate pressures. The one-pass conversion of MPHC is $85 \%$, which provides oil refineries with the processing flexibility to produce ultra-high-quality premium middle distillates (Hilbert et al, 2008).

Based on the above analysis, we develop Scenarios 10 and 11, as shown in Figs. 4 and 5, respectively. In the two scenarios, instead of FCC, HDC is the key conversion process, i.e., the configurations are HDC-based. As a result of it, the total VGO from vacuum distillation units is used as the feedstock of HDC to maximize high-quality diesel production. Here we assume that the diesel yield of HDC is $55.0 \%$. The feedstock of FCC is Coker Gas Oil (CGO) from cokers and Deasphalted Oil (DAO) from solvent deasphalting units (the yields of CGO and DAO are $25.0 \%$ and $60.0 \%$, respectively). The outputs of various gasoline and diesel components and their proportions in finished gasoline and diesel pools for Scenarios 10 and 11 are estimated and the results are shown in Table 5. 


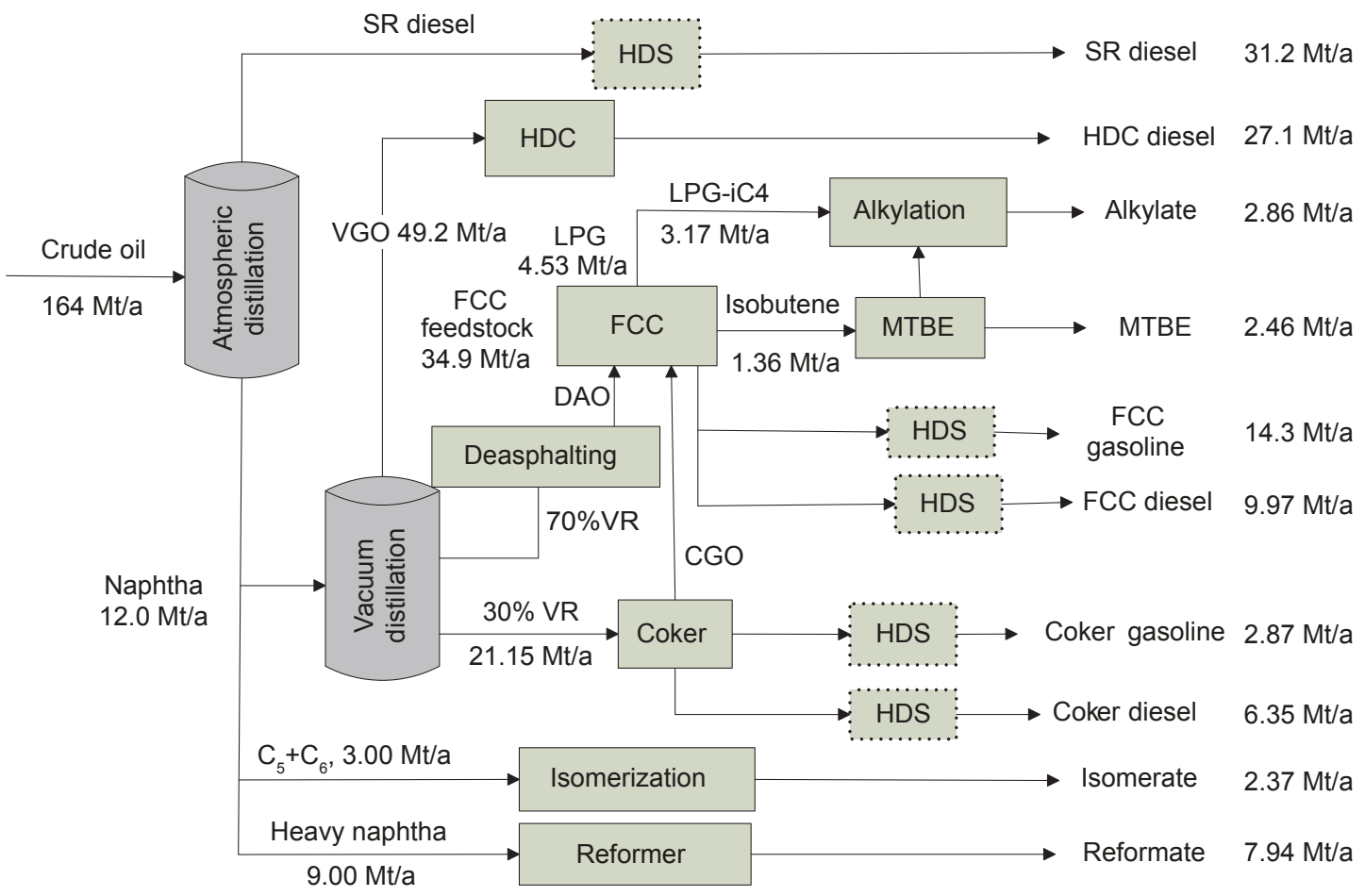

Fig. 4 Scenario 10: configuration of clean gasoline and diesel production units of CNPC in 2015 (HDC-based)

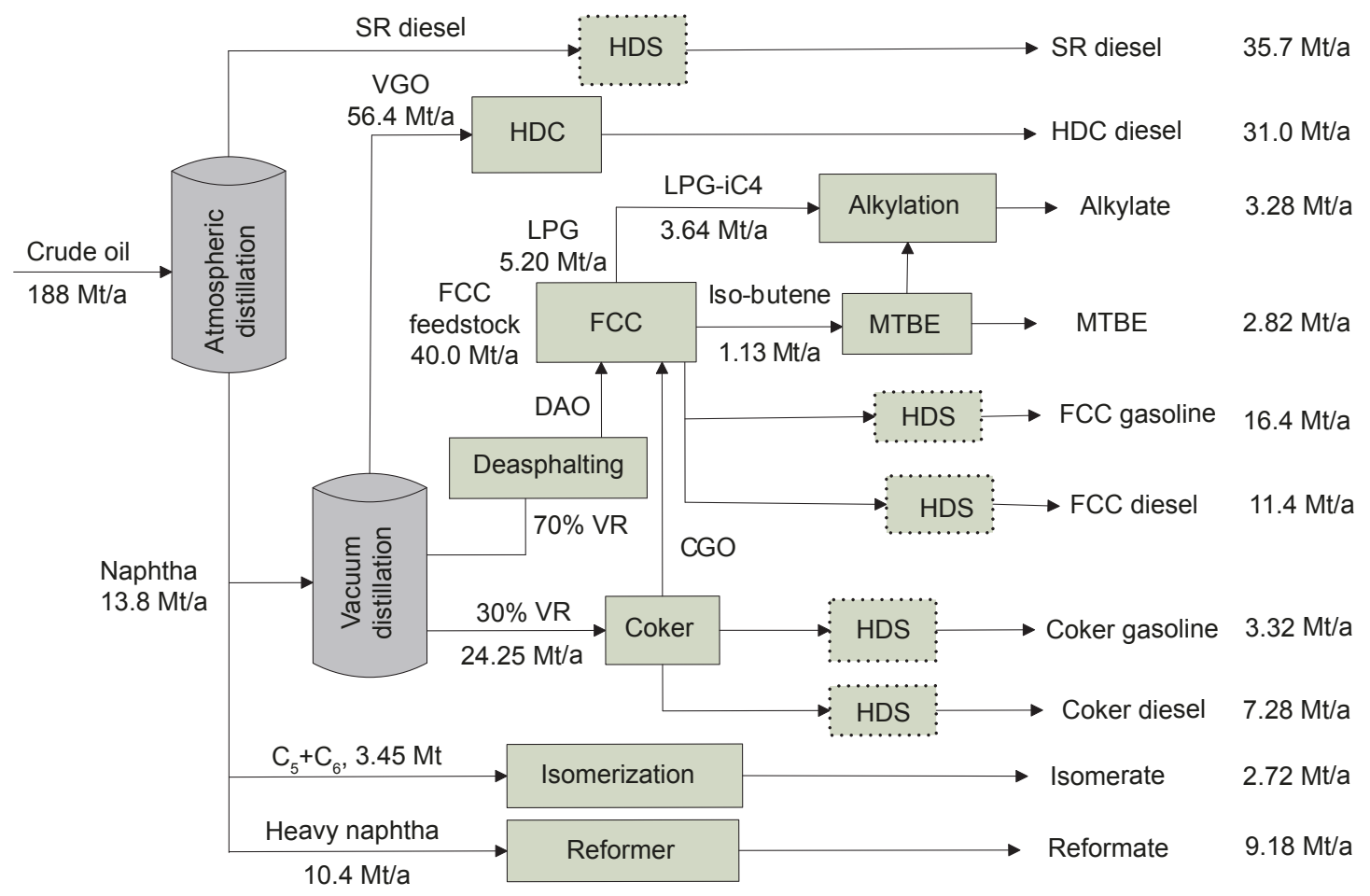

Fig. 5 Scenario 11: configuration of clean gasoline and diesel production units of CNPC in 2020 (HDC-based)

As shown in Fig. 4, in 2015, the processing capacities of HDC and FCC would be 49.2 Mt/a and 34.9 Mt/a, respectively, and the theoretical outputs of finished gasoline and diesel would be 32.80 and 74.62 million tonnes, respectively. More importantly, the diesel to gasoline ratio would be increased from 1.55 of Scenario 8 to 2.27 of Scenario 10 , much close to the diesel/gasoline consumption ratio of 2.30 estimated in literature (Li, 2001). The gasoline and diesel production units are all configured to make clean transportation fuels.

In Scenario 11 for 2020, the processing capacities of HDC and FCC would reach up to $56.4 \mathrm{Mt} / \mathrm{a}$ and $40.0 \mathrm{Mt} / \mathrm{a}$, respectively, resulting in the outputs of gasoline and diesel 
up to 85.38 and 37.72 million tonnes, respectively. Similarly, the diesel to gasoline ratio would reach up to 2.26 , and the configurations of finished gasoline and diesel would be more reasonable than that in Scenario 9.

The above analysis lead to the conclusion that there are two benefits for CNPC to take HDC instead of FCC as its predominant conversion process: one is to increase diesel products, and the other is to upgrade its diesel.

\subsection{Technical challenges for producing clean diesel}

The scenario-based analysis in sections 3.1 and 3.2 strongly suggests that the technical challenge CNPC needs to address will be maximizing diesel output while meeting the stricter fuel quality requirements, particularly the specifications for sulfur, aromatics, and cetane number.
It is well known that many processes, such as hydrotreating of FCC feedstock, HDC, HDT including HDS, HIDS, hydrodenitrogenation (HDN) and hydrodearomatization (HDA), sulfur adsorption, sulfur oxidation and biodesulfurization, can be used to upgrade poor diesel blendstocks. A brief summary of these processes is presented in Table 7. As seen in Table 7, by hydrotreating of FCC feedstocks, sulfur, nitrogen and metals can be removed simultaneously, but the products (gasoline and diesel) need further desulfurization treatment to meet the evertightening low-sulfur fuel specifications. Most importantly, as the predominant transportation fuel production process in China, FCC capacity has been increased up to $120 \mathrm{Mt} / \mathrm{a}$. Hydrotreating of such a large quantity of feedstock involves huge capital investment and operating costs, therefore it can

Table 7 Various diesel upgrading processes (ICCT, 2003)

\begin{tabular}{|c|c|c|c|c|}
\hline Process & Comments & Operating conditions & $\begin{array}{l}\text { Product properties } \\
\qquad(10 \mu \mathrm{g} / \mathrm{g})\end{array}$ & $\operatorname{Cost}^{\mathrm{a}}$ \\
\hline $\begin{array}{l}\text { Hydrotreating of } \\
\text { FCC feedstock }\end{array}$ & $\begin{array}{l}\text { Hydrogenation of feedstock to FCC } \\
\text { with the aim of reducing sulfur levels } \\
\text { in gasoline and diesel together }\end{array}$ & $\begin{array}{l}\text { High temperature and pressure } \\
\text { required; } \\
\text { High reactor volume required due } \\
\text { to the large quantity of feedstock }\end{array}$ & $\begin{array}{c}\text { Products require further } \\
\text { desulfurization to reach } \\
\text { low-sulfur levels; } \\
\text { Reducing nitrogen and metals } \\
\text { that foul FCC units }\end{array}$ & $\begin{array}{l}\text { \$100 million capital \& } \\
\text { high operating cost }\end{array}$ \\
\hline Hydrocracking & $\begin{array}{c}\text { As an alternative to } \mathrm{FCC} \text {, this process } \\
\text { cracks heavy crude fractions and } \\
\text { removes sulfur }\end{array}$ & $\begin{array}{c}\text { Pressure: } 90-180 \text { bar; } \\
\text { Temperature: } 320-410{ }^{\circ} \mathrm{C} \text {; } \\
\text { High hydrogen consumption }\end{array}$ & Raising cetane number & $\begin{array}{l}\text { Unknown capital \& } \\
\text { higher operating cost }\end{array}$ \\
\hline $\begin{array}{l}\text { Hydroteating of } \\
\text { middle distillates }\end{array}$ & $\begin{array}{l}\text { New catalysts and processes can } \\
\text { reduce the reactor volume required and } \\
\text { hydrogen consumption }\end{array}$ & $\begin{array}{c}\text { Pressure: } 32-54 \text { bar; } \\
\text { Temperature: } 300-400{ }^{\circ} \mathrm{C} \text {; } \\
\text { Higher hydrogen consumption; } \\
\text { Moderate to high reactor volumes }\end{array}$ & $\begin{array}{l}\text { Raising cetane number } \\
\text { by } 4 \text { to } 7\end{array}$ & $\begin{array}{l}\$ 40-80 \text { million capital } \\
\& \text { high to moderate } \\
\text { operating cost }\end{array}$ \\
\hline Adsorption & $\begin{array}{l}\text { A desulfurization process that uses a } \\
\text { sorbent in a fluidized bed reactor at } \\
\text { slightly higher temperature and pressure }\end{array}$ & $\begin{array}{c}\text { Pressure: } 34 \text { bar; } \\
\text { Temperature: } 370-420^{\circ} \mathrm{C} \text {; } \\
\text { No net hydrogen consumption; } \\
\text { Moderate reactor volume } \\
\text { requirements }\end{array}$ & $\begin{array}{c}\text { No change in product cetane } \\
\text { number }\end{array}$ & $\begin{array}{l}\text { Unknown capital \& low } \\
\text { to moderate operating } \\
\text { cost }\end{array}$ \\
\hline $\begin{array}{l}\text { Emerging } \\
\text { technologies }\end{array}$ & $\begin{array}{l}\text { Biodedulfurization that uses bacterial } \\
\text { enzymes for sulfur removal; } \\
\text { Chemical oxidation that oxidizes sulfur } \\
\text { with a catalytic acid }\end{array}$ & $\begin{array}{l}\text { The processes are still in the } \\
\text { lab or pilot stage, so operating } \\
\text { conditions are unknown }\end{array}$ & $\begin{array}{l}\text { Additional refinery processes are } \\
\text { required for each technology to } \\
\text { achieve desired sulfur levels }\end{array}$ & $\begin{array}{l}\text { Estimated to be } \$ 35 \\
\text { million capital }\end{array}$ \\
\hline
\end{tabular}

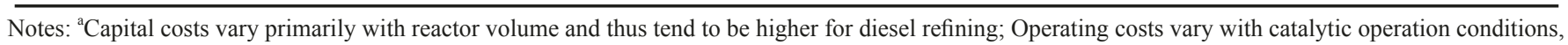
including pressure, temperature, and hydrogen consumption

be hardly used by all the refineries.

The chemical reactions involved in HDC are in nature catalytic cracking ones in the presence of hydrogen. Actually, HDC is one of the most versatile petroleum refining schemes for processing low-value feedstocks, including VGO, DAO, atmospheric gas oils (AGO), LCO, and CGO. According to the analysis in section 3.2 , it can be seen that there are two benefits for CNPC to take HDC instead of FCC as its predominant conversion process: one is to increase diesel products, and the other is to upgrade its diesel. However, the HDC production capacity is highly limited in China, and the high operating cost due to high pressure and high hydrogen consumption would restrict its development in most Chinese refineries. Apart from that, the complexity of the HDC feedstocks in composition creates new challenges for catalyst and process design. Relying on bulk properties of the feedstocks is no longer adequate and understanding the composition at a molecular level becomes necessary. New HDC catalysts and processes should provide not only higher activity and product selectivity but also selective hydrogenation to optimize the hydrogen usage.

Apart from hydrotreating FCC feedstocks and HDC, hydrotreating poor quality diesel such as high-sulfur SR diesel, FCC diesel and coking diesel is another measure 
to upgrade diesel quality. In China, actually, most of the refineries cannot afford to expand their HDC units, which makes the distillates HDT not only the most effective but also the affordable measure for most Chinese refineries to upgrade their finished diesel.

In the past two decades, a variety of distillates HDC and HDT processes and catalysts have been developed and commercialized by major oil companies and catalysts suppliers over the world to produce low-sulfur diesel or ULSD, including the Prime-D technique developed by IFP Axens, Mak-Fining catalysts and the process by ExxonMobil, Akzo Nobel, Kellogg and Fina, the Unionfining technique by UOP-Lurgi, and the SynSat technique by ABB Lummus and Criterion, etc. (Qian, 2003; Zhang, 2008). Meanwhile, being confronted with the national standard GB/T 191472003 on transportation diesel that had come into effect in China in 2005, China's refiners have also developed various HDC and HDT techniques to upgrade their FCC diesel (Zhao, 2008), including single stage hydrotreating (SSHT) techniques developed by Research Institute of Petroleum Processing (RIPP), China Petroleum \& Chemical Corporation (SINOPEC); Maximum cetane improvement (MCI), medium pressure hydroupgrading (MHUG) and flash with countercurrent sulfur-compounds hydrogenation (FCSH) techniques by Fushun Research Institute of Petroleum and Petrochemicals (FRIPP), SINOPEC, and the CK-2 HDS catalyst and the process by CNPC.

The primary purpose of diesel hydrotreatment is to reduce sulfur to low $(<50 \mu \mathrm{g} / \mathrm{g})$ or ultralow $(<10 \mu \mathrm{g} / \mathrm{g})$ levels as well to increase the diesel cetane number by saturating polyaromatic hydrocarbons. Middle distillates like diesel contain many sulfur species such as mercaptans, sulfides, thiophenes, and aromatic sulfur compounds. Sterically hindered dibenzothiophenes (DBT) are a group of aromatic sulfur compounds refractory to hydrotreating, and in hydrotreated diesel their content may still be as high as 500 ppm. To produce ULSD, new catalysts and processes need to be developed for deeply desulfurizing diesel.

In addition to traditional hydrotreating techniques, new techniques such as sulfur adsorption, sulfur oxidation, and biodesulfurization are also under development to reduce the cost of desulfurization, but all these methods are still in their early stage of commercialization (René, 2009).

From the above analysis, it can be concluded that for upgrading its diesel, CNPC needs to upgrade its hydrocracking and hydrotreating technologies in the next 5-10 years. Therefore, the development of highly efficient HDC and HDT catalysts that could improve the cracking activity and product selectivity is the key factor that deserve much attention.

\section{Conclusions}

Using the scenario-analysis method, this paper analyzes how the output and emission related properties of diesel including cetane number and sulfur and aromatics contents produced by CNPC vary with changes in the configuration of diesel production units in the next 5-10 years. The results showed that for CNPC to upgrade its diesel, the ratio of poor
FCC diesel must be reduced, and the ratios of high-quality HDC diesel and HDS diesel should be increased; to meet the tighter and tighter specifications on sulfur and aromatics, SR diesel, as well as FCC diesel and coking diesel should be upgraded by HDT techniques before being blended into the finished diesel pool. Furthermore, to increase its diesel production CNPC needs to take HDC instead of FCC as the predominant conversion process. Developing highly efficient HDC and HDT catalysts and processes are the key for CNPC to economically produce more and cleaner diesel.

\section{References}

David N. Global refining capacity increases slightly in 2006. Oil \& Gas Journal. 2006. 104(47): 56-60

Donald B A, Vasant T and Bart D. Innovative hydrocracking applications for conversion of heavy feedstocks. NPRA Annual Meeting, AM07-47, San Antonio, TX, US. 2007

Hilbert T L, Chitnis G K, Umansky B S, et al. Consider new technology to produce clean diesel. Hydrocarbon Processing. 2008. 87(2): 47-56

Hou F S. Optimizing refining processes for the development of China's petroleum refining industry. Acta Petrolei Sinica (Petroleum Processing Section). 2005. 21(3): 7-16 (in Chinese)

Hou X L. China's Petroleum Refining Technology, 2nd ed (Edited by Hou X L). 2001. Beijing: China Petroleum \& Chemical Corporation Press (in Chinese)

de Jouvenel H. "A Brief Methodological Guide to Scenario Building," Technological Forecasting and Social Change. 2000. 65: 37-48

ICCT (International Council on Clean Transportation ). Low-sulfur gasoline \& diesel: The key to lower vehicle emission. 2003. http:// www.cleantransportcouncil.org

Li Z X. Analysis of and outlook on China diesel demand. International Petroleum Economy. 2001. 9(4): 5-6, 20 (in Chinese)

Liu H Y, Yu J N and Bao X J. Technology foresight in energy industries. Journal of Chemical Industry and Engineering (China). 2006. 57(8): 1817-1826 (in Chinese)

Liu H Y, Yu J N, Fan Y, et al. A scenario-based clean gasoline production strategy for China National Petroleum Corporation. Petroleum Science. 2008. 5(3): 285-294

Ma B W. Technology of clean fuels production. 2001. Beijing: China Petroleum \& Chemical Corporation Press (in Chinese)

PetroChina. Basic Data Collection of Petroleum Refining Units in 2003. 2004. Dalian (in Chinese)

Qian B Z. Advances in catalytic techniques for production of clean gasoline and diesel oil (Cont.). Industrial Catalysis. 2003. 11(3): 1-6 (in Chinese)

René G G. Hydrocracking and hydrotreating developments. Catalysis PTQ. 2009. 14: 15-17

Tian C R. China's oil imports and exports in 2006. International Petroleum Economy. 2007. 15(3): 14-21 (in Chinese)

Wu G J. Cleaner Transportation Fuels. 2004. Beijing: Petroleum Industry Press (in Chinese)

Yuan Q T. Speeding up the progress of petrochemical technologies for sustainable development of petrochemical industries in China. Acta Petrolei Sinica (Petroleum Processing Section). 2005. 21(3): 1-6 (in Chinese)

Zhang D Y. Accelerate the development of hydrogenation processed in China's petroleum industry. Petroleum Refining Engineering. 2008. 38(5): 1-8 (in Chinese)

Zhao Y. Advances in hydrotreating technologies for clean diesel oil. Industrial Catalysis. 2008. 16(1): 10-17 (in Chinese)

(Edited by Zhu Xiuqin) 